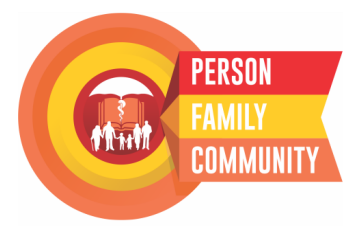

Journal Homepage:

https://jurnal.ugm.ac.id/rpcpe
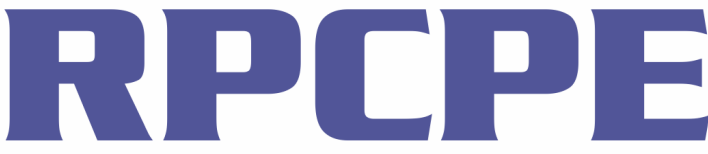

ISSN 2613-943X (print)

ISSN 2620-5572 (online)

Review of Primary Care Practice and Education

(Kajian Praktik dan Pendidikan Layanan Primer)

\title{
Quality of Health Services in the First Level Health Facilities and the Role of Quality and Cost Control Team in Lampung Province
}

\author{
Asep Sukohar ${ }^{1}$, Arli Suryawinata ${ }^{2}$, Aulian Mediansyah ${ }^{3}$ \\ ${ }^{1,2,3}$ Department of Pharmacology; Faculty of Medicine; Universitas Lampung; Indonesia \\ Corresponding Author: \\ Asep Sukohar: Department of Pharmacology; Faculty of Medicine; Universitas Lampung, J1. Prof. Dr. Sumantri Brojonegoro No. 1 \\ Bandar Lampung - 35145, Indonesia \\ E-mail: asepsukohar@gmail.com
}

To cite this article:

Sukohar A, Suryawinata A, Mediansyah A. Quality of health services in the first level health facilities and the role of quality and cost control team in Lampung Province. Rev Prim Care and Educ. 2020; 3(1): 8-14.

\begin{abstract}
Background: The National Health Insurance/Jaminan Kesehatan Nasional (JKN) program is a public health protection guarantee held by the Social Securite Management Agency/Badan Penyelenggara Jaminan Sosial Kesehatan (BPJS) to ensure that all Indonesians receive comprehensive, fair, and equitable health care benefits. The health services are provided using a tiered service system with the first stage in the First Level Health Facilities/Fasilitas Kesehatan Tingkat Pertama (FKTP) acting as a gatekeeper. In conducting these duties, they must always be maintained with good cost-efficiency to be able to provide optimal health service quality. The audit function is imposed by the Quality and Cost Control Team/Tim Kendali Mutu Kendali Biaya (TKMKB) which partners with BPJS. Until now, various efforts to improve the quality of services continue to be developed, one of which is the capitation-based service commitment/Kapitasi Berbasis Komitmen Pelayanan (KBK) payment method. Quality of health services in FKTP can be seen through the high number of FKTP that are affected by the capitation-based service commitment (FKTP KBK-K) payment. Additionally, the high number of FKTP KBK-K can also be a measure of the success of the quality and cost control program implemented by the regional TKMKB. Objective: To assess the quality of health services in FKTP and the TKMKB performance of Lampung Province. Methods: This research was a descriptive-analytic study using data from the BPJS report of Lampung Province and TKMKB in the first and second quarters of 2019. Results: There was an increase in the number of FKTP KBK-K in Lampung Province in the second quarter of 2019, not achieving the minimum contact number, with a low ratio of Prolanis Routine Participants Visiting/Rasio Peserta Prolanis Rutin Berkunjung (RPPRB) especially at the FKTP non-Primary Health Care Centers (non-Puskesmas) in Lampung Province. Conclusion: An increase in the number of FKTP KBK-K that is not accompanied by an increase in the clinical ability of primary health care providers (such as family doctors/primary care doctors) can reflect suboptimal health services in FKTP. Also, this can further serve as a benchmark that the performance of the provincial TKMKB is not yet optimal.
\end{abstract}

Keywords: FKTP, KBK, TKMKB, quality of health services

\section{INTRODUCTION}

National Health Insurance/Jaminan Kesehatan Nasional $(\mathrm{JKN})$ is a guarantee of health protection to ensure that people get the benefits of health care and protection in meeting the basic health needs provided to everyone who has paid contributions or paid by the government ${ }^{1}$. Through the JKN program held by BPJS Kesehatan, the government is presently attempting to ensure that all Indonesians are protected by comprehensive, fair, and equitable health insurance where implementation was started since January $1,2014^{2,3}$.

Community Health Insurance Scheme/Jaminan Kesehatan Masyarakat (Jamkesmas) program is an innovation made by the Indonesian government to provide health services to its people. However, the design and implementation of the program must be based on good information and policy analysis. Policy analysis must be conducted systematically and carefully which includes the design of packages in the program, eligibility criteria for various socioeconomic and occupational groups, financing of medical devices, payment of service providers, and various regulations that include sanctions in the event of violations by either participants or service providers ${ }^{4}$.

According to Indonesia - Health Financing System Assessment: Spend More, Right, and Better, all this time Indonesia is still less effective in implementing JKN, both in terms of service quality, lack of guarantee funds for the level of health promotion and prevention, as well as the high level of expenditure for the treatment of chronic diseases that can be prevented ${ }^{5}$.

A recent report from Indonesia found that over the past 20 years, the number of communicable diseases has decreased significantly, while the number of chronic diseases has increased. Thus, strengthening health services should pay more attention to efforts at prevention medicine more optimally ${ }^{6}$. 
Health services provided by BPJS Kesehatan include individual health service efforts, including promotive, preventive, curative, and rehabilitative done by the government, local government, and/or the community. The JKN service system is a tiered service in which the FKTP includes Puskesmas, Pratama clinics or equivalent, practicing doctors, dentists, and D-class Pratama hospitals or equivalent which act as a gatekeeper, namely health facilities who made the first health care contact with participants ${ }^{7}$.

In various studies around the world, it has been proven that countries that have health care providers at the level of family doctors or primary service doctors will improve the quality of primary services. Prevention will be prioritized, and patient satisfaction increases because services are centered on patients so that health costs can automatically be optimized ${ }^{8}$.

The quality of assurance services provided by the BPJS Kesehatan can be assessed by the establishment of TKMKB following BPJS Kesehatan Regulation No. 8 of 2016 on the Implementation of Quality and Cost Control in the Implementation of the National Health Insurance, TKMKB is a team formed to carry out the role of auditing and verification of the implementation of the BPJS Kesehatan to achieve good service quality and appropriate health service costs. Various types of measurements, standards, and efforts to improve the quality of services continue to be developed, one of which is the KBK payment method ${ }^{9,10}$.

In the implementation of $\mathrm{KBK}$, there are the reward model and the consequences of fulfilling service commitments, a.k.a. FKTP performance. If the performance is optimal, then the FKTP will get a maximum capitation rate, and vice versa, FKTP will get the consequences in the form of a reduction in the amount of payment if there are indicators that cannot be fulfilled. This is part of the development of a service quality control system for the efficiency and effectiveness of health services in FKTP ${ }^{9}$.

Indicators that become the basis of health services quality assessment includes (1) Contact Numbers; (2) NonSpecialistic Outpatient Referral Ratio/Rasio Rujukan Rawat
Jalan Non-Spesialistik (RRNS); and (3) Ratio of RPPB to FKTP. So, with the determination of these indicators, quality and cost control efforts can be done by (1) Controlling the Non-Specialistic Visit/Kunjungan Non-Spesialistik (KNS) in the hospital. The smaller the KNS number means the referral control from the FKTP to the Advanced Nursing Health Facility/Fasilitas Kesehatan Rawat Tingkat Lanjut (FKRTL) is getting better; (2) Implementing the Referral Program/Program Rujukan Balik (PRB). Through PRB, the chronic disease patients whose condition is stable are directed to control and take drugs to the nearest FKTP, not necessarily to FKRTL; and (3) Implementing the quality referrals ${ }^{9,10,11}$.

The number of health facilities affected by the KBK payment consequences can indicate how the quality of health services in an area. However, this can also be a success measure of the quality and cost control program which is implemented by TKMKB.

Based on the explanation above, it is considered important to assess how the quality of health services in an area can also reflect the work effectiveness of provincial TKMKB to continue maintaining and improving the quality of national health services, especially in regions with indications of suboptimal quality.

\section{RESEARCH METHODS}

This research is a descriptive-analytic study using data from the BPJS Kesehatan report of Lampung Province and the work report of TKMKB in the first and second quarters of 2019. Then these data are grouped by category to see the distribution of data in general and the distribution per district/city.

\section{RESULTS}

Lampung Province KBKP Monev reports in the first and second quarters of 2019 show that there was an increase in the number of FKTP who underwent a Cooperation Agreement/Perjanjian Kerja Sama (PKS) of 6 health facilities. However, this was also followed by an increase in the percentage of the number of FKTP affected by the KBK (KBK-K) payment, namely 327 FKTP (53.43\%) from 303 FKTP $(50 \%)$ in the first quarter.

Table 1. The number of FKTP affected by the KBK payment consequences in Lampung Province

\begin{tabular}{|c|c|c|c|c|c|c|c|c|c|c|}
\hline \multirow{2}{*}{ FKTP Type } & \multicolumn{5}{|c|}{ Until March 2019} & \multicolumn{5}{|c|}{ Until June 2019} \\
\hline & FKTP PKS & KBK-K & KBK-TK & Non-KBK & $\% \mathrm{KBK}-\mathrm{K}$ & FKTP PKS & KBK-K & KBK-TK & Non-KBK & $\% \mathrm{KBK}-\mathrm{K}$ \\
\hline Puskesmas & 299 & 288 & 11 & - & $96.32 \%$ & 302 & 291 & 11 & - & $96.36 \%$ \\
\hline $\begin{array}{l}\text { Indonesian } \\
\text { National Army } \\
\text { Clinic }\end{array}$ & 13 & - & 10 & 3 & $0.00 \%$ & 12 & - & 9 & 3 & $0.00 \%$ \\
\hline $\begin{array}{l}\text { Republic of } \\
\text { Indonesia Police } \\
\text { Clinic }\end{array}$ & 11 & - & 8 & 3 & $0.00 \%$ & 11 & - & 8 & 3 & $0.00 \%$ \\
\hline Pratama Clinic & 155 & 15 & 118 & 22 & $9.68 \%$ & 153 & 34 & 98 & 21 & $22.22 \%$ \\
\hline Doctor Practice & 128 & - & 102 & 26 & $0.00 \%$ & 134 & 2 & 104 & 28 & $1.49 \%$ \\
\hline Total & 606 & 303 & 249 & 54 & $50.00 \%$ & 612 & $* 327$ & 230 & 55 & $53.43 \%$ \\
\hline
\end{tabular}

*: The number of FKTP KBK-K throughout the Lampung Province until the second quarter of 2019

Lampung Province has three BPJS Branch Office/ Kantor Cabang (KC), namely KC Bandar Lampung, KC Kotabumi, and $\mathrm{KC}$ Metro. From the three $\mathrm{KC}, \mathrm{KC}$ Metro is the $\mathrm{KC}$ with the highest number of FKTP KBK-K, i.e. 134 of the 225 health facilities in the scope of work. 
Table 2. The number of FKTP affected by the KBK payment consequences per KC of BPJS

\begin{tabular}{|c|c|c|c|c|c|c|c|c|c|c|c|c|}
\hline \multirow{2}{*}{ FКTP Type } & \multicolumn{4}{|c|}{ KC Bandar Lampung } & \multicolumn{4}{|c|}{ KC Kotabumi } & \multicolumn{4}{|c|}{ KC Metro } \\
\hline & PKS & KBK-K & KBK-TK & Non-KBK & PKS & KBK-K & KBK-TK & Non KBK & PKS & KBK-K & KBK-TK & Non-KBK \\
\hline Puskesmas & 104 & 96 & 8 & - & 70 & 67 & 3 & - & 128 & 128 & - & - \\
\hline $\begin{array}{l}\text { Indonesian } \\
\text { National Army } \\
\text { Clinic }\end{array}$ & 7 & - & 7 & - & 3 & - & - & 3 & 2 & - & 2 & - \\
\hline $\begin{array}{l}\text { Clinic } \\
\text { Republic of } \\
\text { Indonesia Police } \\
\text { Clinic }\end{array}$ & 4 & - & 4 & - & 3 & - & - & 3 & 4 & - & 4 & - \\
\hline $\begin{array}{l}\text { Type D Pratama } \\
\text { Hospital }\end{array}$ & - & - & - & - & - & - & - & - & - & - & - & - \\
\hline Pratama Clinic & 84 & 27 & 57 & - & 26 & 1 & 4 & 21 & 43 & 6 & 37 & - \\
\hline Doctor Practice & 58 & 2 & 56 & - & 28 & - & - & 28 & 48 & - & 48 & - \\
\hline Total & 257 & 125 & 132 & - & 130 & 68 & 7 & 55 & 225 & $* 134$ & 91 & - \\
\hline
\end{tabular}

*: KC of BPJS Kesehatan with the highest number of FKTP KBK-K in the second quarter of 2019

Table 3. The number of FKTP affected by the KBK payment consequences per district/city

\begin{tabular}{|c|c|c|c|c|c|c|c|c|c|c|}
\hline \multirow[t]{2}{*}{ District/City } & \multicolumn{5}{|c|}{ Until March 2019} & \multicolumn{5}{|c|}{ Until June 2019} \\
\hline & FKTP PKS & KBK-K & KBK-TK & Non-KBK & $\% \mathrm{KBK}-\mathrm{K}$ & FKTP PKS & KBK-K & KBK-TK & Non-KBK & $\% \mathrm{KBK}-\mathrm{K}$ \\
\hline Bandar Lampung City & 93 & 34 & 59 & - & $37 \%$ & 93 & 45 & 48 & - & $48 \%$ \\
\hline $\begin{array}{l}\text { Lampung Selatan } \\
\text { District }\end{array}$ & 72 & 27 & 45 & - & $38 \%$ & 72 & 30 & 42 & - & $42 \%$ \\
\hline Pesawaran District & 23 & 14 & 9 & - & $61 \%$ & 23 & 17 & 6 & - & $74 \%$ \\
\hline Pringsewu District & 35 & 13 & 22 & - & $37 \%$ & 35 & 17 & 18 & - & $49 \%$ \\
\hline Tanggamus District & 35 & 15 & 20 & - & $43 \%$ & 35 & 16 & 19 & - & $46 \%$ \\
\hline Lampung Barat District & 22 & 15 & 1 & 6 & $68 \%$ & 22 & 15 & 1 & 6 & $68 \%$ \\
\hline Lampung Utara District & 52 & 28 & - & 24 & $54 \%$ & 53 & 28 & 1 & 24 & $53 \%$ \\
\hline Pesisir Barat District & 14 & 6 & 3 & 5 & $43 \%$ & 14 & 6 & 3 & 5 & $43 \%$ \\
\hline Way Kanan District & 40 & 19 & 2 & 19 & $48 \%$ & 41 & 19 & 2 & 20 & $46 \%$ \\
\hline $\begin{array}{l}\text { Lampung Tengah } \\
\text { District }\end{array}$ & 78 & 43 & 35 & - & $55 \%$ & 80 & 44 & 36 & - & $55 \%$ \\
\hline $\begin{array}{l}\text { Lampung Timur } \\
\text { District }\end{array}$ & 57 & 35 & 22 & - & $61 \%$ & 57 & 35 & 22 & - & $61 \%$ \\
\hline Mesuji District* & 16 & 12 & 4 & - & $75 \%$ & 17 & 13 & 4 & - & $76 \%$ \\
\hline Metro District & 28 & 18 & 10 & - & $64 \%$ & 25 & 13 & 12 & - & $52 \%$ \\
\hline Tulang Bawang District & 17 & 10 & 7 & - & $59 \%$ & 27 & 17 & 10 & - & $63 \%$ \\
\hline $\begin{array}{l}\text { Tulang Bawang Barat } \\
\text { District }\end{array}$ & 25 & 13 & 12 & - & $52 \%$ & 19 & 12 & 7 & - & $63 \%$ \\
\hline Total & 607 & 302 & 251 & 54 & $50 \%$ & 613 & 327 & 231 & 55 & $53 \%$ \\
\hline
\end{tabular}

*: District with the highest number of FKTP KBK-K until the second quarter of 2019

When viewed from the reports per district/city, Mesuji Regency is the locus with the highest percentage of FKTP KBK-K at $76 \%$ (13 of 17 FKTP), then the lowest percentage of FKTP KBK-K is found in South Lampung Regency, which is $42 \%$ (30 of 72 FKTP), while Bandar Lampung City which is the capital of a province with the highest number of FKTP has a percentage of KBK-K FKTP as much as $48 \%$ (45 of 93 FKTP).

Further analysis shows that the indicator that causes the large number of FKTP KBK-K is the low number of contacts and RPPB. The contact number indicator shows that although the average FKTP in Lampung Province shows an increase, the average achievement rate until the

Table 4. Percentage of contact numbers achievement in FKTP in Lampung Province

\begin{tabular}{lllll}
\hline \multirow{2}{*}{ Dati 2 Name } & \multicolumn{2}{c}{ Puskesmas } & \multicolumn{2}{c}{ Non-Puskesmas } \\
\cline { 2 - 5 } & Quarter I & Quarter II & Quarter I & Quarter II \\
\hline Lampung Selatan District & 49.99 & 59.06 & 122.48 & 121.85 \\
Pesawaran District & 141.66 & 143.34 & 142.60 & 149.70 \\
Pringsewu District & 77.68 & 88.90 & 118.59 & 114.04 \\
Tanggamus District & 116.25 & 106.28 & 194.44 & 158.48 \\
Bandar Lampung City & 97.87 & 94.40 & 120.54 & 113.89 \\
Lampung Barat District & 123.13 & 138.65 & 130.84 & 126.33 \\
Lampung Utara District & 59.99 & 54.75 & 129.37 & 124.93 \\
Pesisir Barat District & 78.59 & 124.28 & 89.38 & 143.58 \\
Way Kanan District & 139.43 & 130.12 & 91.97 & 97.97 \\
Lampung Tengah District & 110.77 & 116.46 & 138.89 & 127.34 \\
Lampung Timur District & 96.29 & 96.25 & 149.62 & 142.02 \\
Mesuji District & 126.22 & 120.54 & 155.47 & 133.72 \\
Tulang Bawang District & 88.56 & 81.58 & 138.76 & 123.63 \\
Tulang Bawang Barat District & 142.58 & 127.29 & 121.75 & 124.00 \\
Metro District & 127.37 & 127.15 & 145.57 & 117.51 \\
Total & 103.50 & $105.85^{*}$ & 131.76 & $128.68^{*}$ \\
\hline
\end{tabular}

*: The total achievements of the FKTP contact numbers in Lampung Province have not yet reached the minimum standard of national achievement 
Table 5. Percentage of RPPB contact numbers achievement in FKTP in Lampung Province

\begin{tabular}{lllll}
\hline \multirow{2}{*}{ Dati 2 Name } & \multicolumn{2}{c}{ Puskesmas } & \multicolumn{2}{c}{ Non-Puskesmas } \\
\cline { 2 - 5 } & Quarter I & Quarter II & Quarter I & Quarter II \\
\hline Lampung Selatan District & 42.28 & 43.90 & 22.99 & 28.60 \\
Pesawaran District & 69.37 & 71.39 & 31.67 & 35.31 \\
Pringsewu District & 80.00 & 71.04 & 22.33 & 25.15 \\
Tanggamus District & 46.42 & 54.02 & 37.33 & 43.74 \\
Bandar Lampung City & 83.18 & 78.72 & 28.21 & 25.94 \\
Lampung Barat District & 45.08 & 50.79 & 27.09 & 22.59 \\
Lampung Utara District & 40.36 & 30.31 & 28.62 & 26.20 \\
Pesisir Barat District & 50.26 & 57.44 & 2.71 & 2.37 \\
Way Kanan District & 50.54 & 54.13 & 15.76 & 19.23 \\
Lampung Tengah District & 53.62 & 61.68 & 33.00 & 30.52 \\
Lampung Timur District & 51.91 & 59.18 & 40.28 & 32.76 \\
Mesuji District & 65.36 & 63.92 & 29.08 & 16.78 \\
Tulang Bawang District & 45.07 & 44.20 & 27.44 & 24.57 \\
Tulang Bawang Barat District & 72.73 & 52.25 & 37.39 & 39.19 \\
Metro District & 45.01 & 49.49 & 23.88 & 22.36 \\
Total & 56.87 & 56.64 & 27.42 & $26.64 *$ \\
*: The total achievements of RPPB & FKTP & non-Puskesmas & in & Lampung Province have not \\
reached the minimum standard of national achievement & &
\end{tabular}

second quarter of 2019 is still below the national indicator standards $(\min >150 \%)$.

The achievement of the RPPB indicators shows that up to the second quarter of 2019 there was a downward trend compared to the first quarter of 2019. Even so, in terms of the average percentage of Puskesmas RPPBs were still above the national boundary, the focus of the problem was on the non-Puskesmas FKTP RPPB numbers, where there were none of the FKTP non-Puskesmas in Lampung Province which have RPPB numbers above $50 \%$.

RRNS indicator achievements were also analyzed and showed that all FKTP in Lampung Province already had RRNS numbers below $5 \%$.

Table 6. Percentage of RNS contact numbers achievement in FKTP in Lampung Province

\begin{tabular}{lllll}
\hline \multirow{2}{*}{ Dati 2 Name } & \multicolumn{3}{c}{ Puskesmas } & \multicolumn{2}{c}{ Non-Puskesmas } \\
\cline { 2 - 5 } & Quarter I & Quarter II & Quarter I & Quarter II \\
\hline Lampung Selatan District & 1.85 & 1.38 & 2.98 & 2.38 \\
Pesawaran District & 0.75 & 0.19 & 1.40 & 1.15 \\
Pringsewu District & 0.60 & 0.17 & 2.55 & 1.46 \\
Tanggamus District & 1.15 & 1.26 & 2.90 & 2.70 \\
Bandar Lampung City & 0.43 & 0.41 & 2.66 & 1.22 \\
Lampung Barat District & 1.11 & 1.84 & 0.03 & 0.43 \\
Lampung Utara District & 2.12 & 1.50 & 3.06 & 1.37 \\
Pesisir Barat District & 0.45 & 0.26 & - & - \\
Way Kanan District & 0.87 & 1.11 & 0.81 & 0.21 \\
Lampung Tengah District & 0.69 & 0.65 & 0.43 & - \\
Lampung Timur District & 0.61 & 0.39 & 1.78 & 1.21 \\
Mesuji District & 1.31 & 0.60 & - & - \\
Tulang Bawang District & - & - & 2.94 & 0.60 \\
Tulang Bawang Barat District & 0.21 & - & 0.88 & 2.25 \\
Metro District & 0.06 & 0.13 & 0.42 & 0.28 \\
Total & 0.87 & $0.70^{*}$ & 1.60 & $1.07^{*}$ \\
*: The total achievements of RNS & FKTP in Lampung Province have reached the minimum \\
standard of national achievement & \multicolumn{4}{l}{}
\end{tabular}

\section{DISCUSSION}

Based on the results of data analysis, it is known that the main problems involve indicators that have not been reached optimally in the quality control and optimal cost control processes which are not fulfilling the minimum contact number $(\min >150 \%)$ and the low number of RPPB to FKTP ( $\min >50 \%)$. Although on average FKTP in Lampung Province shows an increase in contact numbers, the contact numbers until the second quarter of 2019 are still below the national indicator standards. When reviewed by the district, only non-Puskesmas FKTPs in Tanggamus District had more than $150 \%$ contact numbers.

The low achievement of contact numbers in FKTP must be a serious concern because contact numbers are an indicator to find out the level of accessibility and utilization of primary services in FKTP per month both inside and outside the building without considering the frequency of attendance of participants in one month. Utilization referred to here is utilization through direct contact both sick contact and healthy contact. So, the low contact number achievement in an FKTP can be an indicator of non-progressive and preventive efforts in the FKTP. This is certainly not following the FKTP service concept which should prioritize promotive and preventive measures ${ }^{10,12}$.

The role of primary service providers such as family doctors/primary care doctors is to improve access to health 
services through home visits, counseling, group counseling, and family empowerment. Primary service providers are expected to master these service methods, so that first contact with patients will be effective ${ }^{8}$. Contact with patients is not just about meeting patients but investing time in the initial assessment of the patient's health problems. The better the method used and the more time spent in this first contact, the more effective health services will be. A concrete example is the prevention and monitoring of DM type II sufferers. DM sufferers' understanding of the disease they suffer, when they make first contact with a family doctor / primary care doctor, will greatly affect the speed of the natural course of the disease. If health care providers are skilled in providing patient-centered services, including the process of sharing information and discussing clinical decisions, then the complications of the disease are expected to be more controlled. This is compared to DM sufferers who lack understanding of the disease, due to lack of information from health care providers and who are less able to discuss the problem because the first contact is meaningless/just meeting alone ${ }^{8}$.

Thus, in FKTP that has fulfilled the standards for contact number achievement, it is also necessary to do a deeper search related to those contact number achievements. Because it does not rule out the possibility that FKTP is merely trying to meet the target contact number which is $>$ $150 \%$, where as long as it meets the target other registered participants are not contacted. Besides, a deeper search for contact numbers will also reduce the likelihood that FKTP will re-enter the participant numbers that have previously been entered in the previous month. To avoid the occurrence of the above allegations, the BPJS Kesehatan must give orders to the FKTP leadership to ensure a well-documented visit data recapitulation (including participant data, card numbers, especially on healthy visits/activities outside the building) and to ensure that all visits are made in real input time $^{13,12,14}$.

The achievement of the RPPB indicators is still a problem, where all FKTP non-Puskesmas in Lampung Province show an average RPPB achievement below $<50 \%$. This is of course also a problem because FKTP as a gatekeeper has the function of maintaining continuity of health services. FKTP has the main functions, namely: (1) First contact (contact/first service provider): (2) Continuity (continuity service); (3) Comprehensiveness (comprehensive service); and (4) Coordination ${ }^{15}$. Whereas health service performance indicators in FKTP are assessed through: (1) Functional indicator that includes first contact and continuity; (2) Clinical indicators include participants' health outcomes and adherence to clinical guidelines; and (3) Financial indicators includes referral and visit numbers ${ }^{9}$.

The implementation of capitation payments based on fulfilling service commitments is assessed based on the achievement of indicators that include: (1) Contact numbers, an indicator to determine the level of accessibility and utilization of primary services in FKTP by participants based on the number of JKN participants (per participant identification number) who receive health services in FKTP per month, both inside the building and outside the building without taking into account the frequency of attendees in one month; (2) RRNS, which is an indicator to find out the quality of service in FKTP so that the referral system is organized according to medical indications and FKTP competencies; and (3) RPPRB to FKTP, is an indicator to know the continuity of chronic disease services agreed by BPJS Health and FKTP to Prolanis participants. If one of the indicators cannot reach the minimum standard, then BPJS Health has the authority to not pay in full the amount of payment that must be paid ${ }^{12}$.

According to BPJS rules as covered in Presidential Regulation Number 111 of 2013, the First Level Health Facility (FKTP) is an institution entitled to provide nonspecialized health services which include things such as promotive and preventive services; medical examination, treatment and consultation; non-specialistic medical procedures, both operative and non-operative; service of medicines and medical consumables, and other concerns ${ }^{16}$. The goal is to be able to do the screening which will be used to prevent complications in patients to reduce the number of referrals and costs in FKRTL. However, FKTP is still entitled to refer patients if further treatment is needed by a specialist doctor or requires facilities that are not available in FKTP. The FKTP institution will refer patients to FKTL ${ }^{10}$.

The low number of RPPB will hamper the process of continuing health services because patients will come continuously with the same complaints to get a referral to FKRTL. Patients with stable chronic diseases should be managed at FKTP through PRB. One of the causes of the low RPPB is that PRB drugs are not available at FKTP, so patients always look for ways to be referred to FKRTL to get better treatment ${ }^{7}$.

PRB is one of the excellent programs to improve the quality of health services for BPJS Kesehatan participants and facilitate access to health services for participants with chronic diseases. PRB services are provided to participants of BPJS Kesehatan sufferers of chronic diseases that are already controlled/stable but still need treatment or nursing care in the long run. With the implementation of PRB in the management of patients with chronic diseases, it is expected that the referral rate can be controlled, so that FKRTL is not burdened to manage the same patients, with the same complaints. If this can be done optimally, the quality of health services provided will improve because the path of patient management is clear and ongoing to completion ${ }^{17}$.

One way to increase the number of RPPB is through optimizing the implementation of Prolanis by selecting participants through screening as well as being selective of participants with Prolanis diagnoses for the referral. Also, BPJS Kesehatan must ensure the availability of PRB drugs through increased collaboration with PRB pharmacies, so that Prolanis patients do not need to continue to be referred every time they want to take PRB drugs ${ }^{17}$.

Although RNS data shows that all FKTPs in each district/ city is below the national standard, if a deeper investigation is done, there are still some FKTPs that have RNS above $5 \%$. This has led to more supervisory performance so that 
FKTP which has problems in the RNS achievements will be further assisted. Even if possible, the RNS rate in all FKTP can reach $0 \%$ following the provisions of the Indonesian Medical Competency Standards, i.e. patients who do not require specialist management must be completed at a general practitioner.

Efforts to reduce the number of RNS can be done by increasing the agreement on peer review diagnosis and the provision of appropriate drugs to support the completion of the peer review diagnosis at FKTP. Moreover, it can be done by increasing the competence of doctors in FKTP by mentoring specialists or providing seminars/workshops related to peer review diagnosis ${ }^{12}$.

All of the descriptions of the achievement indicators of FKTP service quality above, both contact numbers, RNS, and RPPB, cannot be separated from the involvement of TKMKB as partners to carry out periodic utilization of medical reviews and audits on FKTP. So that one of the optimal indicators of regional TKMKB performance is an improvement from the achievement of the indicators above. This contrasts with the available data because the FKTP indicator achievements tend to show a negative trend. So, the results of this data analysis can also be input for the Lampung Province TKMKB to improve its performance, as well as an input for the Central TKMKB to review how the process is conducted by the provincial TKMKB. There is one possibility of not achieving optimal performance from the provincial TKMKB which is the lack of sufficient budget to conduct regular audits.

\section{CONCLUSION}

There was an increase in the number of FKTP KBK-K in Lampung Province in the second quarter of 2019, not achieving the minimum contact number, and the low number of RPPB, especially in non-Puskesmas FKTP in Lampung Province. This description of an increase in the number of FKTP KBK-K can reflect the quality of health services in FKTP is still not optimal. This problem must be a top priority in efforts to improve the quality of health services further, because these indicators are the main function of FKTP, namely as the first and sustainable service providers.

The increase in the number of FKK KBK-K can also illustrate the sub-optimal performance of provincial TKMKB. Accordingly, the next step is to improve the performance of the Lampung Province TKMKB to do periodic utilization of medical reviews and audits conducted with the branch BPJS.

\section{Acknowledgments}

Thanks go to the Bandar Lampung Branch BPJS for facilitating this research in the hope of contributing to the improvement of health services at FKTP.

\section{Ethical Approval and Informed Consent}

Ethical approval of this study was issued by the Faculty of Medicine, the University of Lampung with No. 295/ UN26.18/PP.05.02.00//2019.

\section{Funding}

TKMKB-BPJS Bandar Lampung fund.

\section{Availability of Data and Material}

Corresponding author.

\section{Conflict of Interest}

None.

\section{REFERENCES}

1. Ministry of Health Republic of Indonesia. Ministry of health regulation no. 71 of 2013 on health services on national health insurance. Republic of Indonesia Public Letter of 2013 No. 1400. Jakarta: Ministry of Health Republic of Indonesia; 2013.

2. Putri AE. Understand BPJS: badan penyelenggara jaminan sosial/ social security management agency. Jakarta: Friedrich-EbertStiftung; 2014.

3. Republic of Indonesia. Act no. 24 of 2011 on social security management agency article 1 section 1. Republic of Indonesia State Gazette of 2011 No. 116. Jakarta: State Secretariat; 2011.

4. Rokx C, Schieber G, Harimurti P, Tandon A, Somanathan A. Health financing in Indonesia: a reform road map. Washington, D.C: World Bank; 2009

5. Tandon A, Pambudi ES, Harimurti P, Masaki E, Subandoro AW, Yasmin Chrysanti P, Rajan VS, Dorkin DW, Chandra A, Boundreaux C, Pei Lyn MC, Suharno N. Indonesia - health financing system assessment: spend more, right, and better. Washington, D.C: World Bank; 2016.

6. Mboi N, Surbakti IM, Trihandini I, Elyazar I, Smith KH, Ali PB, Kosen S, Flemons K, Ray SE, Cao J, Glenn SD, Miller-Petrie MK, Mooney MD, Ried JL, Ningrum DNA, Idris F, Siregar KN, Harimurti P, Bernstein RS, Pangestu T, Sidharta Y, Naghavi M, Murray CJL, Hay SI. On the road to universal health care in Indonesia, 1990-2016: a systematic analysis for the global burden of disease study 2016. The Lancet. 2018; 392(10147): 581-91.

7. Christasani PD, Satibi S. Study of demographic factors on national health insurance patient satisfaction at first-level health facilities. Journal of Pharmaceutical Sciences \& Community. 2016; 13(1): 2834.

8. WONCA. Contributions of family medicine to improve the health system $2^{\text {nd }}$ ed. Jakarta: EGC; 2017.

9. BPJS Kesehatan. BPJS kesehatan regulation no. 8 of 2016 on the implementation of quality and cost control in the implementation of the national health insurance. Republic of Indonesia Public Letter of 2016 No. 2069. Jakarta: BPJS Kesehatan; 2016.

10. Ministry of Health Republic of Indonesia, BPJS Kesehatan. Joint regulations of the secretary-general of the Ministry of Health of the Republic of Indonesia and the managing director of BPJS Kesehatan no. HK.01.08/III/980/2017 no. 2 of 2017 on technical instructions for implementing capitation payments based on fulfilling service commitments at first-level health facilities. Jakarta: Ministry of Health Republic of Indonesia, BPJS Kesehatan; 2017.

11. Ministry of Health Republic of Indonesia. Handbook on the socialization of national health insurance on the national social security system. Jakarta: Ministry of Health Republic of Indonesia; 2016. Available from: http://www.depkes.go.id/resources/download/ $\mathrm{jkn} /$ buku-pegangan-sosialisasi-jkn.pdf

12. Syamsuri E. Capitation is based on fulfilling the commitment to optimization services and expanding implementation at private FKTP (clinic/DPP). Bandar Lampung: BPJS Kesehatan Bandar Lampung; 2019.

13. BPJS Kesehatan. BPJS Kesehatan prioritizes the quality of health facilities at the first level [Internet]. 2015. [Updated 20 January 2015; cited 5 September 2018]. Available from: https://bpjs-kesehatan.go.id/ bpjs/index.php/post/read/2015/314/BPJS-Kesehatan-PentingkanKualitas-Faskes-Tingkat-Pertama

14. Fachrurrazi. KBKP monev in the second quarter of 2019 in Lampung Province. Bandar Lampung: BPJS Kesehatan Bandar Lampung; 2019.

15. Starfield B. Primary care: balancing health needs, services, and technology. New York: Oxford University Press; 1998.

16. Republic of Indonesia. Presidential regulation no. 111 of 2013 on the 
14 Asep Sukohar et al. | Quality of Health Services in the First Level Health Facilities and... | Research Article

changes of presidential regulation no. 12 of 2013 on health insurance. Republic of Indonesia State Gazette of 2013 No. 255. Jakarta: State Secretariat; 2013.
17. BPJS Kesehatan Bandar Lampung. Implementation of the referral program. Bandar Lampung: BPJS Kesehatan Bandar Lampung; 2018. 